\title{
Unprecedented Chemical Transformation of Benzaldehyde Semicarbazone Mediated by Osmium
}

\author{
Parna Gupta, ${ }^{1 \mathrm{a}}$ Falguni Basuli, ${ }^{1 \mathrm{a}}$ Shie-Ming Peng, ${ }^{1 \mathrm{~b}}$ Gene-Hsiang Lee, ${ }^{1 \mathrm{~b}}$ and Samaresh Bhattacharya ${ }^{*}, 1 \mathrm{a}$ \\ Department of Chemistry, Inorganic Chemistry Section, Jadavpur University, \\ Kolkata 700 032, India, and Department of Chemistry, National Taiwan University, \\ Taipei, Taiwan, ROC
}

Received November 2, 2002

\begin{abstract}
para-Nitrobenzaldehyde semicarbazone $\left(\mathrm{O}_{2} \mathrm{~N}(\right.$ para $\left.)-\mathrm{C}_{6} \mathrm{H}_{4} \mathrm{C}(\mathrm{H})=\mathrm{N}-\mathrm{NH}-\mathrm{CO}-\mathrm{NH}_{2}\right)$ undergoes unprecedented chemical transformation during its reaction with $\left[\mathrm{Os}\left(\mathrm{PPh}_{3}\right)_{2}(\mathrm{CO})_{2}(\mathrm{HCOO})_{2}\right]$ in different alcoholic $\left(\mathrm{R}^{\prime} \mathrm{OH}, \mathrm{R}^{\prime}=\right.$ $\mathrm{CH}_{2} \mathrm{CH}_{2} \mathrm{OCH}_{3}, \mathrm{CH}_{2} \mathrm{CH}_{3}, \mathrm{CH}_{2} \mathrm{CH}_{2} \mathrm{CH}_{3}$, and $\mathrm{CH}_{2} \mathrm{CH}_{2} \mathrm{CH}_{2} \mathrm{CH}_{3}$ ) solvents whereby the $\mathrm{NH}_{2}$ group of the semicarbazone ligand is displaced by a $\mathrm{OR}^{\prime}$ group provided by the solvents. The transformed semicarbazone ligand binds to osmium as a bidentate $\mathrm{N}, \mathrm{O}-$-donor forming five-membered chelate ring to afford complexes of type $\left[\mathrm{Os}\left(\mathrm{PPh}_{3}\right)_{2^{-}}\right.$ $\left.(\mathrm{CO})(\mathrm{H})\left(\mathrm{L}-\mathrm{O} \mathrm{R}^{\prime}\right)\right]$, where L-OR' refers to the transformed semicarbazone ligand. Structure of the $\left[\mathrm{Os}\left(\mathrm{PPh}_{3}\right)_{2}(\mathrm{CO})\right.$ $\left.(\mathrm{H})\left(\mathrm{L}-\mathrm{OCH}_{2} \mathrm{CH}_{2} \mathrm{OCH}_{3}\right)\right]$ complex has been determined by X-ray crystallography. All the $\left[\mathrm{Os}\left(\mathrm{PPh}_{3}\right)_{2}(\mathrm{CO})(\mathrm{H})\left(\mathrm{L}-\mathrm{OR} \mathrm{R}^{\prime}\right)\right]$ complexes are diamagnetic and show characteristic ${ }^{1} \mathrm{H}$ NMR signals. They also show intense absorptions in the visible and ultraviolet region. Cyclic voltammetry on the complexes shows an irreversible oxidative response within $0.69-0.88 \mathrm{~V}$ versus SCE.
\end{abstract}

\section{Introduction}

Though the chemistry of transition metal complexes of the semicarbazone and thiosemicarbazone ligands has been receiving considerable attention primarily because of their bioinorganic relevance, ${ }^{2}$ we have been studying the chemistry of the platinum metal complexes of these ligands with special reference to the variable coordination modes displayed by these ligands in their complexes. ${ }^{3}$ During our recent exploration of the coordination chemistry of the benzaldehyde semicarbazones (1), we have observed that in their reaction

* To whom correspondence should be addressed. E-mail: samaresh_b@ hotmail.com.

(1) (a) Jadavpur University. (b) National Taiwan University.

(2) (a) Dimmock, J. R.; Puthucode, R. N.; Smith, J. M.; Hetherington, M.; Quail, J. W.; Pugazhenthi, U.; Lechler, J.; Stables, J. P. J. Med. Chem. 1996, 39, 3984. (b) West, D. X.; Liberta, A. E.; Padhye, S. B.; Chikate, R. C.; Sonawane, P. B.; Kumbhar, A. S.; Yerande, R. G. Coord. Chem. Rev. 1993, 123, 49. (c) West, D. X.; Padhye, S. B.; Sonawane, P. B. Struct. Bonding (Berlin) 1992, 76, 1. (d) Haiduc, I.; Silvestru, C. Coord. Chem. Rev. 1990, 99, 253. (e) Padhye, S. B.; Kauffman, G. B. Coord. Chem. Rev. 1985, 63, 127. (f) Campbell, M. J. M. Coord. Chem. Rev. 1975, 15, 279.

(3) (a) Dutta, S.; Basuli, F.; Peng, S. M.; Lee, G. H.; Bhattacharya, S. New. J. Chem. 2002, 26, 1607. (b) Basuli, F.; Peng, S. M.; Bhattacharya, S. Inorg. Chem. 2001, 40, 1126. (c) Pal, I.; Basuli, F.; Mak, T. C. W.; Bhattacharya, S. Angew. Chem., Int. Ed. 2001, 40, 2923. (d) Basuli, F.; Peng, S. M.; Bhattacharya, S. Inorg. Chem. 2000, 39, 1120. (e) Basuli, F.; Ruf, M.; Pierpont, C. G.; Bhattacharya, S. Inorg. Chem. 1998, 39, 6113. (f) Basuli, F.; Peng, S. M.; Bhattacharya, S. Inorg. Chem. 1997, 36, 5645.

10.1021/ic026154s CCC: $\$ 25.00$ C 2003 American Chemical Society Published on Web 02/15/2003

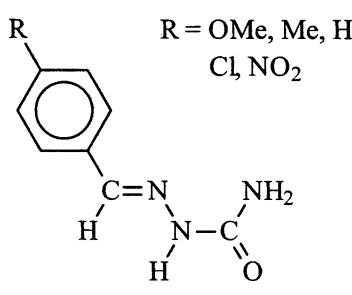

1

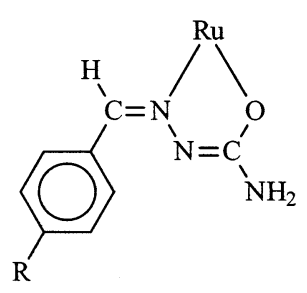

3<smiles>[R]C1=[N+](N)OC1[R1]</smiles>

2

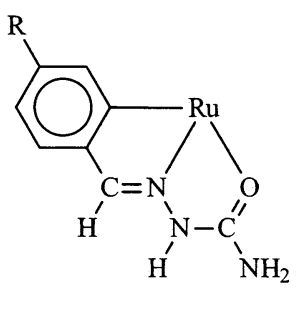

4 with ruthenium these semicarbazone ligands display three different coordination modes $(\mathbf{2}, \mathbf{3}$, and $\mathbf{4})$ depending on the nature of the ruthenium starting materials and the experimental conditions as well. ${ }^{3 b}$ This has encouraged us to explore the coordination chemistry of these semicarbazone ligands with the next congener of ruthenium, viz. osmium. It is interesting to note here that though transition metal 
Gupta et al.

complexes of the semicarbazone ligands have been studied well, ${ }^{2 \mathrm{e}}$ the osmium chemistry of the benzaldehyde semicarbazones appears to have remained unexplored. For the present study, we have chosen the $\left[\mathrm{Os}\left(\mathrm{PPh}_{3}\right)_{2}(\mathrm{CO})_{2}(\mathrm{HCOO})_{2}\right]$ complex as the osmium starting material. This particular complex has recently been synthesized in our laboratory, and it has already demonstrated its ability as an efficient synthon, which is believed to be due mainly to the labile nature of the formate ligands. ${ }^{4}$ Reaction of each of the five semicarbazone ligands (1) has been carried out with $\left[\mathrm{Os}\left(\mathrm{PPh}_{3}\right)_{2}-\right.$ $\left.(\mathrm{CO})_{2}(\mathrm{HCOO})_{2}\right]$ in several alcoholic $\left(\mathrm{R}^{\prime} \mathrm{OH}\right)$ solvents. However, except the para-nitrobenzaldehyde semicarbazone, the other semicarbazone ligands have not afforded any characterizable complexes. During its reaction with the $\left[\mathrm{Os}\left(\mathrm{PPh}_{3}\right)_{2}-\right.$

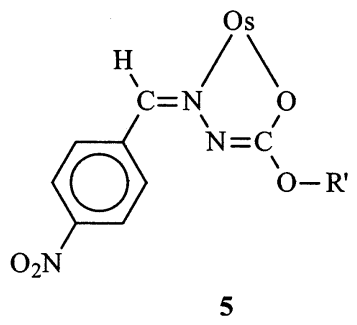

$(\mathrm{CO})_{2}(\mathrm{HCOO})_{2}$ ] complex, the para-nitrobenzaldehyde semicarbazone ligand has been found to undergo an interesting chemical transformation via reaction with the alcoholic $\left(\mathrm{R}^{\prime} \mathrm{OH}\right)$ solvent and bind to osmium as a bidentate N,O-donor (5) affording complexes of type $\left[\mathrm{Os}\left(\mathrm{PPh}_{3}\right)_{2}(\mathrm{CO})(\mathrm{H})\left(\mathrm{L}-\mathrm{OR}^{\prime}\right)\right]$, where L-OR' refers to the transformed semicarbazone ligand in 5. An account of the chemistry of these $\left[\mathrm{Os}\left(\mathrm{PPh}_{3}\right)_{2}(\mathrm{CO})\right.$ $\left.(\mathrm{H})\left(\mathrm{L}_{-} \mathrm{OR}^{\prime}\right)\right]$ complexes is described in this paper with special reference to their formation, structure, and spectroscopic and electrochemical properties.

\section{Experimental Section}

Materials. Commercial osmium tetroxide was purchased from Arora Matthey, Kolkata, India, and was converted to $\left[\mathrm{NH}_{4}\right]_{2}\left[\mathrm{OsBr}_{6}\right]$ by reduction with hydrobromic acid. ${ }^{5}\left[\mathrm{Os}\left(\mathrm{PPh}_{3}\right)_{3} \mathrm{Br}_{2}\right]$ was synthesized, starting from $\left[\mathrm{NH}_{4}\right]_{2}\left[\mathrm{OsBr}_{6}\right]$, by following a reported procedure. ${ }^{6}\left[\mathrm{Os}\left(\mathrm{PPh}_{3}\right)_{2}(\mathrm{CO})(\mathrm{HCOO})_{2}\right]$ was prepared as before. ${ }^{4}$ Purification of dichloromethane and preparation of tetrabutylammonium perchlorate (TBAP) for electrochemical work were performed as reported in the literature. ${ }^{7}$ All other chemicals and solvents were reagent grade commercial materials and were used as received.

Preparations of Complexes. All the $\left[\mathrm{Os}\left(\mathrm{PPh}_{3}\right)_{2}(\mathrm{CO})(\mathrm{H})\left(\mathrm{L}-\mathrm{OR}^{\prime}\right)\right]$ $\left(\mathrm{R}^{\prime}=\mathrm{CH}_{2} \mathrm{CH}_{2} \mathrm{OCH}_{3}, \mathrm{CH}_{2} \mathrm{CH}_{3}, \mathrm{CH}_{2} \mathrm{CH}_{2} \mathrm{CH}_{3}, \mathrm{CH}_{2} \mathrm{CH}_{2} \mathrm{CH}_{2} \mathrm{CH}_{3}\right)$ complexes were prepared in 55-65\% yield by following a general procedure. Specific details are given below for a particular complex.

$\left[\mathrm{Os}\left(\mathrm{PPh}_{3}\right)_{2}(\mathrm{CO})(\mathrm{H})\left(\mathrm{L}-\mathrm{OCH}_{2} \mathrm{CH}_{2} \mathrm{OCH}_{3}\right)\right]$. To a hot solution of 4-nitrobenzaldehyde semicarbazone ( $24 \mathrm{mg}, 0.12 \mathrm{mmol}$ ) in 2-methoxyethanol $(40 \mathrm{~mL})$ was added $\left[\mathrm{Os}\left(\mathrm{PPh}_{3}\right)_{2}(\mathrm{CO})(\mathrm{HCOO})_{2}\right](100 \mathrm{mg}$, $0.12 \mathrm{mmol}$ ). The mixture was heated at reflux for $24 \mathrm{~h}$ to produce

(4) Gupta, P.; Basuli, F.; Peng, S. M.; Lee, G. H.; Bhattacharya, S. Submitted for publication.

(5) Dwyer, F. P.; Hogarth, J. W. Inorg. Synth. 1957, 5, 204.

(6) Hoffman, P. R.; Caulton, K. G. J. Am. Chem. Soc. 1975, 97, 4221

(7) (a) Sawyer, D. T.; Roberts, J. L., Jr. Experimental Electrochemistry for Chemists; Wiley: New York, 1974; pp 167-215. (b) Walter, M.; Ramaley, L. Anal. Chem. 1973, 45, 165.
Table 1. Crystallographic Data for $\left[\mathrm{Os}\left(\mathrm{PPh}_{3}\right)_{2}(\mathrm{CO})(\mathrm{H})\left(\mathrm{L}-\mathrm{OCH}_{2} \mathrm{CH}_{2} \mathrm{OCH}_{3}\right)\right]$

\begin{tabular}{ll}
\hline empirical formula & $\mathrm{C}_{50} \mathrm{H}_{46} \mathrm{~N}_{3} \mathrm{O}_{6} \mathrm{OsP}_{2}$ \\
$\mathrm{fw}$ & 1051.05 \\
space group & orthorhombic, $P 2{ }_{1} 2_{1} 2_{1}$ \\
$a, \AA$ & $14.6729(9)$ \\
$b, \AA$ & $16.0198(10)$ \\
$c, \AA$ & $19.3962(12)$ \\
$V, \AA$ & $4559.2(5)$ \\
$Z$ & 4 \\
$\lambda, \AA$ & 0.71073 \\
cryst size, $\mathrm{mm}^{3}$ & $0.35 \times 0.15 \times 0.15$ \\
$T, \mathrm{~K}$ & $150(1)$ \\
$\mu, \mathrm{mm}^{-1}$ & 2.921 \\
$\mathrm{R}^{a}$ & 0.0282 \\
$\mathrm{wR}^{b}$ & 0.0660 \\
$\mathrm{GOF}^{c}$ & 1.006
\end{tabular}

${ }^{a} \mathrm{R} 1=\sum|| F_{\mathrm{o}}|-| F_{\mathrm{c}}\left|/ \sum\right| F_{\mathrm{o}} \mid \cdot{ }^{b} \mathrm{wR} 2=\left[\sum\left\{w\left(F_{\mathrm{o}}{ }^{2}-F_{\mathrm{c}}{ }^{2}\right)^{2}\right\} / \sum\left\{w\left(F_{\mathrm{o}}{ }^{2}\right)\right\}\right]^{1 / 2}$ ${ }^{c} \mathrm{GOF}=\left[\sum\left(w\left(F_{\mathrm{o}}{ }^{2}-F_{\mathrm{c}}\right)^{2}\right) /(M-N)\right]^{1 / 2}$, where $M$ is the number of reflections and $N$ is the number of parameters refined.

an orange solution. Evaporation of this solution gave an orange solid, which was subjected to thin-layer chromatography on a silica plate. With toluene as the eluant, an orange band separated out. The orange band was extracted with acetonitrile, and slow evaporation of the acetonitrile extract gave $\left[\mathrm{Os}\left(\mathrm{PPh}_{3}\right)_{2}(\mathrm{CO})(\mathrm{H})\left(\mathrm{L}_{-} \mathrm{OCH}_{2-}\right.\right.$ $\mathrm{CH}_{2} \mathrm{OCH}_{3}$ )] as an orange crystalline solid. Yield: $60 \%$.

Physical Measurements. Microanalyses $(\mathrm{C}, \mathrm{H}, \mathrm{N})$ were performed using a Heraeus Carlo Erba 1108 elemental analyzer. IR spectra were obtained on a Perkin-Elmer 783 spectrometer with samples prepared as $\mathrm{KBr}$ pellets. Electronic spectra were recorded on a JASCO V-570 spectrophotometer. ${ }^{1} \mathrm{H}$ NMR spectra were obtained on a Bruker Avance DPX 300 NMR spectrometer using TMS as the internal standard. Electrochemical measurements were made using a CH Instruments model 600A electrochemical analyzer. A platinum disk working electrode, a platinum wire auxiliary electrode, and an aqueous saturated calomel reference electrode (SCE) were used in a three-electrode configuration. Electrochemical experiments were performed under a dinitrogen atmosphere. All electrochemical data were collected at $298 \mathrm{~K}$ and are uncorrected for junction potentials.

Crystallography of [Os( $\left.\left(\mathrm{PPh}_{3}\right)_{2}(\mathrm{CO})(\mathrm{H})\left(\mathrm{L}-\mathrm{OCH}_{2} \mathrm{CH}_{2} \mathrm{OCH}_{3}\right)\right]$. Single crystals of $\left[\mathrm{Os}\left(\mathrm{PPh}_{3}\right)_{2}(\mathrm{CO})(\mathrm{H})\left(\mathrm{L}-\mathrm{OCH}_{2} \mathrm{CH}_{2} \mathrm{OCH}_{3}\right)\right]$ were obtained by slow evaporation of acetonitrile solution of the complex. Selected crystal data and data collection parameters are given in Table 1. Data were collected on a Bruker Smart CCD diffractometer using graphite monochromated $\operatorname{Mo} K \alpha$ radiation $(\lambda=0.71073 \AA)$ by $\phi$ and $\omega$ scans within the $\theta$ range $1.65-27.50^{\circ}$. X-ray data reduction, structure solution, and refinement were done using SHELXS-97 and SHELXL-97 programs. ${ }^{8}$ The structure was solved by the direct methods.

\section{Results and Discussion}

Reaction of the para-nitrobenzaldehyde semicarbazone with $\left[\mathrm{Os}\left(\mathrm{PPh}_{3}\right)_{2}(\mathrm{CO})_{2}(\mathrm{HCOO})_{2}\right]$ was first carried out in refluxing 2-methoxyethanol, which afforded a crystalline orange complex in decent yield. Preliminary characterization (elemental analysis, IR, ${ }^{1} \mathrm{H}$ NMR, etc.) on this complex (vide infra) could not point to any definite composition. Identity of the complex has finally been revealed by its structure determination by X-ray crystallography. The structure is

(8) Sheldrick, G. M. SHELXS-97 and SHELXL-97, Fortran programs for crystal structure solution and refinement; University of Gottingen: Gottingen, Germany, 1997. 
(a)

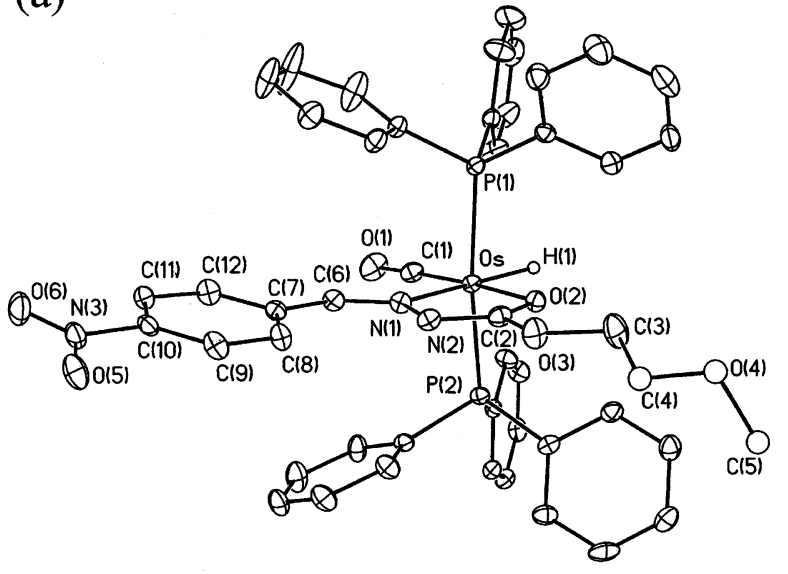

(b)

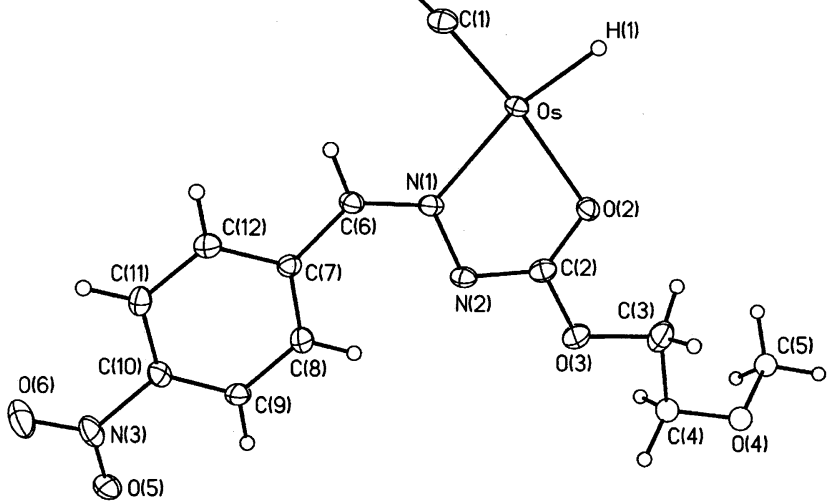

Figure 1. View of (a) the $\left[\mathrm{Os}\left(\mathrm{PPh}_{3}\right)_{2}(\mathrm{CO})(\mathrm{H})\left(\mathrm{L}-\mathrm{OCH}_{2} \mathrm{CH}_{2} \mathrm{OCH}_{3}\right)\right]$ complex and (b) the $\mathrm{Os}(\mathrm{CO})(\mathrm{H})\left(\mathrm{L}-\mathrm{OCH}_{2} \mathrm{CH}_{2} \mathrm{OCH}_{3}\right)$ fragment.

Table 2. Selected Bond Distances and Bond Angles for $\left[\mathrm{Os}\left(\mathrm{PPh}_{3}\right)_{2}(\mathrm{CO})(\mathrm{H})\left(\mathrm{L}-\mathrm{OCH}_{2} \mathrm{CH}_{2} \mathrm{OCH}_{3}\right]\right.$

\begin{tabular}{llll}
\multicolumn{5}{c}{ Bond Distances $(\AA)$} \\
$\mathrm{Os}-\mathrm{H}(1)$ & $1.60(4)$ & $\mathrm{N}(1)-\mathrm{N}(2)$ & $1.379(4)$ \\
$\mathrm{Os}-\mathrm{C}(1)$ & $1.838(5)$ & $\mathrm{N}(2)-\mathrm{C}(2)$ & $1.316(5)$ \\
$\mathrm{Os}-\mathrm{N}(1)$ & $2.139(3)$ & $\mathrm{C}(2)-\mathrm{O}(2)$ & $1.282(5)$ \\
$\mathrm{Os}-\mathrm{O}(2)$ & $2.125(3)$ & $\mathrm{C}(2)-\mathrm{O}(3)$ & $1.337(5)$ \\
$\mathrm{Os}-\mathrm{P}(1)$ & $2.3478(10)$ & $\mathrm{O}(3)-\mathrm{C}(3)$ & $1.447(6)$ \\
$\mathrm{Os}-\mathrm{P}(2)$ & $2.3469(10)$ & $\mathrm{C}(3)-\mathrm{C}(4)$ & $1.648(9)$ \\
$\mathrm{C}(1)-\mathrm{O}(1)$ & $1.158(5)$ & $\mathrm{C}(4)-\mathrm{O}(4)$ & $1.309(10)$ \\
$\mathrm{C}(6)-\mathrm{N}(1)$ & $1.303(5)$ & $\mathrm{O}(4)-\mathrm{C}(5)$ & $1.664(13)$ \\
\multicolumn{5}{c}{} \\
$\mathrm{P}(1)-\mathrm{Os}-\mathrm{P}(2)$ & $171.40(4)$ & $\mathrm{C}(1)-\mathrm{Os}-\mathrm{O}(2)$ & $173.43(16)$ \\
$\mathrm{H}(1)-\mathrm{Os}-\mathrm{N}(1)$ & $166.3(14)$ & $\mathrm{N}(1)-\mathrm{Os}-\mathrm{O}(2)$ & $74.52(11)$
\end{tabular}

shown in Figure 1, and selected bond parameters are listed in Table 2. The structure shows that during the course of the synthetic reaction, the semicarbazone ligand has undergone an unusual chemical transformation. The $\mathrm{NH}_{2}$ fragment of the semicarbazone ligand has been replaced by a $\mathrm{OCH}_{2}-$ $\mathrm{CH}_{2} \mathrm{OCH}_{3}$ fragment provided by the solvent. The modified semicarbazone ligand is coordinated to osmium as a bidentate N,O-donor forming a five-membered chelate ring (5). This particular coordination mode of the semicarbazone ligand is also quite unusual as it involves, with reference to the structure of the uncoordinated ligand (1), ${ }^{9}$ an interesting conformational change across the imine $(\mathrm{C}=\mathrm{N})$ bond. Besides the semicarbazone, two $\mathrm{PPh}_{3}$ ligands, one $\mathrm{CO}$, and

(9) Naik, D. V.; Palenik, G. J. Acta Crystallogr., Sect. B 1974, 30, 2396. a hydride $\left(\mathrm{H}^{-}\right)$are also coordinated to osmium. The expelled formate ligand or the solvent probably has served as the source of the hydride. This complex is therefore represented as $\left[\mathrm{Os}\left(\mathrm{PPh}_{3}\right)_{2}(\mathrm{CO})(\mathrm{H})\left(\mathrm{L}-\mathrm{OCH}_{2} \mathrm{CH}_{2} \mathrm{OCH}_{3}\right)\right]$, where $\left(\mathrm{L}-\mathrm{OCH}_{2}-\right.$ $\mathrm{CH}_{2} \mathrm{OCH}_{3}$ ) stands for the transformed semicarbazone ligand coordinated to osmium. The coordinated semicarbazone, $\mathrm{CO}$, and hydride ligands constitute the equatorial plane of the octahedron with the metal ion at the center. The $\mathrm{CO}$ and the hydride are trans respectively to the oxygen and nitrogen of the semicarbazone ligand. The two $\mathrm{PPh}_{3}$ ligands have occupied the remaining two axial positions, and hence, they are mutually trans. The $\mathrm{Os}-\mathrm{H}$, Os $-\mathrm{C}$, Os $-\mathrm{N}$, and $\mathrm{Os}-\mathrm{O}$ distances are all quite normal, as observed in structurally characterized complexes of osmium(II) containing these bonds. ${ }^{10}$ However, the Os $-\mathrm{P}$ distances are a bit shorter than usually observed in complexes of osmium(II) having the trans-Os $\left(\mathrm{PPh}_{3}\right)_{2}$ fragment. ${ }^{10 \mathrm{c}-\mathrm{g}, \mathrm{i}}$ Comparison of the bond lengths in the coordinated semicarbazone ligand with those in the free semicarbazone ligand ${ }^{9}$ shows that upon coordination the $\mathrm{C}-\mathrm{O}$ bond has elongated while the adjacent $\mathrm{C}-\mathrm{N}$ bond (which is part of the chelate ring) has contracted. These changes in bond lengths are attributable to stabilization of the iminolate form of the semicarbazone ligand upon complexation via loss of the hydrazinic proton.

The observed transformation of the semicarbazone ligand not only is unusual, but also appears to be unprecedented. Treatment of the semicarbazone ligand with the refluxing solvent (2-methoxyethanol) alone (for $24 \mathrm{~h}$ ) failed to bring about any chemical change in the semicarbazone, which indicates that the observed transformation has been mediated by the metal center. The mechanism of this interesting chemical transformation, as well as the unusual conformational change of the semicarbazone ligand, is not completely clear to us. However, the sequences shown in Scheme 1 seem probable. In the initial step, the semicarbazone coordinates to osmium through the imine nitrogen, which favors dissociation of the hydrazinic proton. The negative charge, thus generated, gets delocalized over the para-nitrophenyl ring causing a temporary decrease in the imine bond order. This is followed by the conformational change, driven probably by steric interaction between the aryl ring and osmium. ${ }^{3 \mathrm{~d}}$ The conformational change seems to be associated with simultaneous coordination from the oxygen, which enhances the electrophilicity of the next carbon atom. Subsequent nucleophilic attack by the solvent $\left(\mathrm{R}^{\prime} \mathrm{OH}\right)$ at this amide-like carbon finally leads to the observed transformation via elimination of $\mathrm{NH}_{3}$. The other benzaldehyde semicarbazones

(10) (a) Barrio, P.; Esteruelas, M. A.; Õnate, E. Organometallics 2002, 21, 2491. (b) Gusev, D. G.; Kuhlman, R. L.; Renkema, K. B. Eisenstein, O.; Caulton, K. G. Inorg. Chem. 1996, 35, 6775. (c) Robinson, P. D.; Hinckley, C. C.; Ikuo, A. Acta Crystallogr. 1988, C44, 1491. (d) Pramanik, K.; Shivakumar, M.; Ghosh, P.; Chakravorty, A. Inorg. Chem. 2000, 39, 195. (e) Das, A.; Basuli, F.; Peng, S. M.; Bhattacharya, S. Polyhedron 1999, 18, 2729. (f) Rickard, C. E. F.; Roper, W. R.; Woodgate, S. D.; Wright, L. J. J. Organomet. Chem. 2002, 643-644, 168. (g) Rickard, C. E. F.; Roper, W. R.; Williamson, A.: Wright, L. J. Organometallics 2002, 21, 1714. (h) Yandulov, D. V.; Huffman, J. C.; Caulton, K. G. Organometallics 2002, 21, 4030. (i) Rickard, C. E. F.; Roper, W. R.; Williamson, A.; Wright, L. J. Organometallics 2002, 21, 4862. (j) Esteruelas, M. A.; Gonzalez, A I.; Lopez, A. M.; Õnate, E. Organometallics 2003, 22, 414. 
Gupta et al.

Scheme 1. Probable Steps in the Formation of the $\left[\mathrm{Os}\left(\mathrm{PPh}_{3}\right)_{2}(\mathrm{CO})(\mathrm{H})\left(\mathrm{L}-\mathrm{OR}^{\prime}\right)\right]$ Complexes

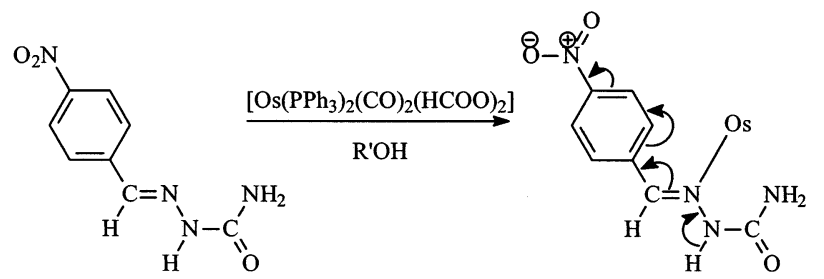

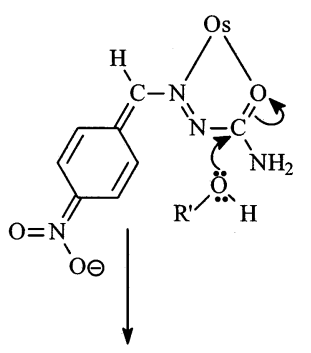

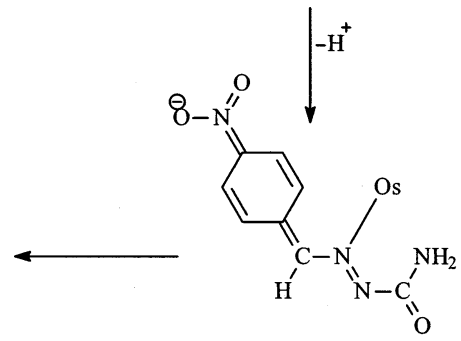

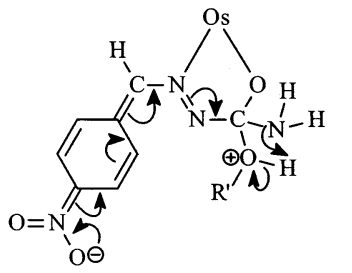<smiles>[R]OC(=N/N=C/c1ccc([N+](=O)[O-])cc1)O[V]</smiles>

$\left(\mathbf{1}, \mathrm{R} \neq \mathrm{NO}_{2}\right)$ could not undergo similar reaction probably because the substituent $\mathrm{R}$ was not enough electron-withdrawing so as to favor delocalization of the negative charge over the aryl ring, which seems to play a key role in the observed transformation.

Encouraged by the interesting reaction of 2-methoxyethanol with para-nitrobenzaldehyde semicarbazone mediated by osmium, similar reactions were also carried out in few other alcoholic solvents (viz. ethanol, $n$-propanol, and $n$-butanol) in order to check whether similar transformation also takes place in these solvents. From each of these reactions, an orange complex of type $\left[\mathrm{Os}\left(\mathrm{PPh}_{3}\right)_{2}(\mathrm{CO})(\mathrm{H})\right.$ $\left(\mathrm{L}-\mathrm{OR}^{\prime}\right.$ )] (where $\mathrm{R}^{\prime}=\mathrm{CH}_{2} \mathrm{CH}_{3}, \mathrm{CH}_{2} \mathrm{CH}_{2} \mathrm{CH}_{3}$, and $\mathrm{CH}_{2} \mathrm{CH}_{2}$ -
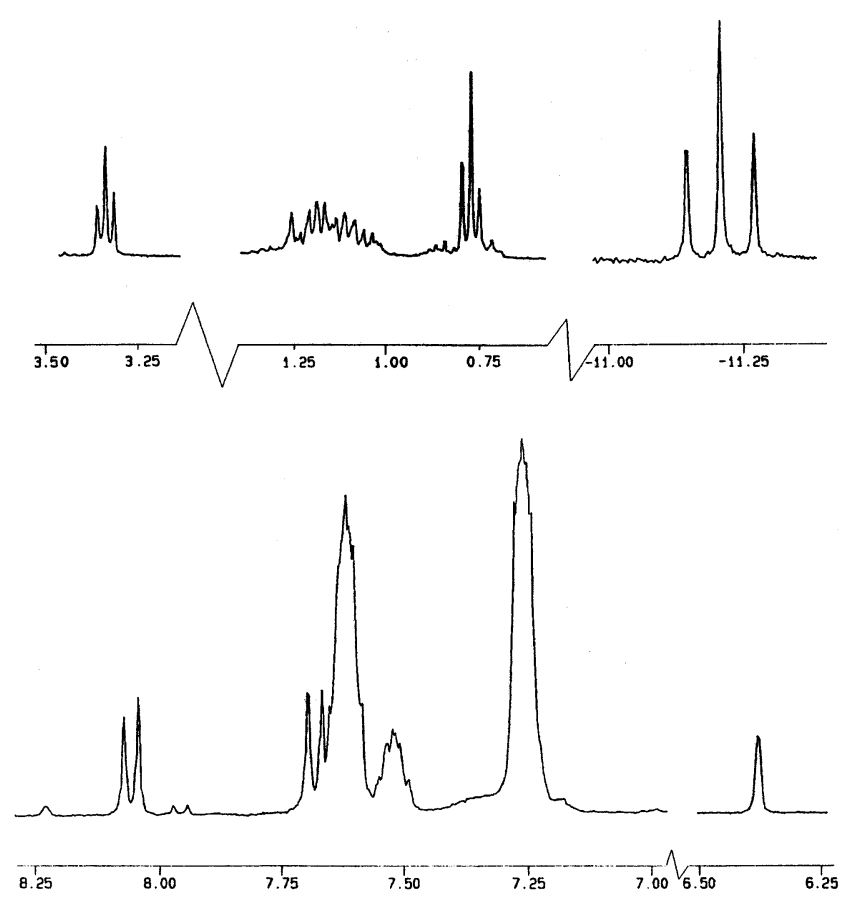

Figure 2. ${ }^{1} \mathrm{H}$ NMR spectrum of $\left[\mathrm{Os}\left(\mathrm{PPh}_{3}\right)_{2}(\mathrm{CO})(\mathrm{H})\left(\mathrm{L}-\mathrm{OCH}_{2} \mathrm{CH}_{2} \mathrm{CH}_{2}-\right.\right.$ $\left.\mathrm{CH}_{3}\right)$ ] in $\mathrm{CDCl}_{3}$ solution.

$\mathrm{CH}_{2} \mathrm{CH}_{3}$ ) has been obtained. Elemental analytical data of all the four $\left[\mathrm{Os}\left(\mathrm{PPh}_{3}\right)_{2}(\mathrm{CO})(\mathrm{H})\left(\mathrm{L}-\mathrm{OR}^{\prime}\right)\right]$ complexes are in good agreement with their composition (Table S1). As all the $\left[\mathrm{Os}\left(\mathrm{PPh}_{3}\right)_{2}(\mathrm{CO})(\mathrm{H})\left(\mathrm{L}-\mathrm{OR}^{\prime}\right)\right]$ complexes have been synthesized similarly and as they exhibit similar properties (vide infra), the latter three $\left[\mathrm{Os}\left(\mathrm{PPh}_{3}\right)_{2}(\mathrm{CO})(\mathrm{H})\left(\mathrm{L}-\mathrm{OR}^{\prime}\right)\right]$ (where $\mathrm{R}^{\prime}$ $=\mathrm{CH}_{2} \mathrm{CH}_{3}, \mathrm{CH}_{2} \mathrm{CH}_{2} \mathrm{CH}_{3}$ and $\mathrm{CH}_{2} \mathrm{CH}_{2} \mathrm{CH}_{2} \mathrm{CH}_{3}$ ) complexes are assumed to have the same structure as $\left[\mathrm{Os}\left(\mathrm{PPh}_{3}\right)_{2}(\mathrm{CO})\right.$ $\left.(\mathrm{H})\left(\mathrm{L}-\mathrm{OCH}_{2} \mathrm{CH}_{2} \mathrm{OCH}_{3}\right)\right]$.

Magnetic susceptibility measurements show that the [Os$\left.\left(\mathrm{PPh}_{3}\right)_{2}(\mathrm{CO})(\mathrm{H})\left(\mathrm{L}-\mathrm{OR}^{\prime}\right)\right]$ complexes are diamagnetic, which corresponds to the +2 state of osmium (low-spin $\mathrm{d}^{6} S=0$ ) in these complexes. ${ }^{1} \mathrm{H}$ NMR spectra of all the complexes have been recorded in $\mathrm{CDCl}_{3}$ solution. Spectral data are given in Table 3, and a selected spectrum is shown in Figure 2. Each complex shows broad signals for the phenyl protons of the $\mathrm{PPh}_{3}$ ligands within 7.2-7.6 ppm. In each complex, the hydride signal is observed as a distinct triplet, due to

Table 3. ${ }^{1} \mathrm{H}$ NMR Data of the Complexes<smiles></smiles>

\begin{tabular}{|c|c|c|c|c|c|}
\hline \multirow[b]{2}{*}{ compd } & \multicolumn{5}{|c|}{ chemical shift in ppm } \\
\hline & $\mathrm{PPh}_{3}$ & $\mathrm{H}_{\mathrm{a}}\left(J_{\mathrm{H}-\mathrm{H}}, \mathrm{Hz}\right), \mathrm{H}_{\mathrm{b}}\left(J_{\mathrm{H}-\mathrm{H}}, \mathrm{Hz}\right)$ & $\mathrm{H}_{\mathrm{c}}$ & $\mathrm{H}_{\mathrm{d}}\left(J_{\mathrm{P}-\mathrm{H}}, \mathrm{Hz}\right)$ & $\mathrm{R}^{\prime}$ \\
\hline$\left[\mathrm{Os}\left(\mathrm{PPh}_{3}\right)_{2}(\mathrm{CO})(\mathrm{H})\left(\mathrm{L}-\mathrm{OCH}_{2} \mathrm{CH}_{2} \mathrm{OCH}_{3}\right)\right]$ & $7.2-7.6$ & $8.05(9.0), 7.69(9.0)$ & 6.35 & $-11.20(18.6)$ & $3.10,^{a} 3.19,{ }^{b} 3.47^{a}$ \\
\hline$\left[\mathrm{Os}\left(\mathrm{PPh}_{3}\right)_{2}(\mathrm{CO})(\mathrm{H})\left(\mathrm{L}-\mathrm{OCH}_{2} \mathrm{CH}_{3}\right)\right]$ & $7.2-7.6$ & $8.05(8.9), 7.66(8.9)$ & 6.44 & $-11.30(18.3)$ & $0.86,{ }^{a} 3.48^{c}$ \\
\hline 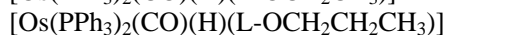 & $7.2-7.6$ & $8.05(8.8), 7.67(8.8)$ & 6.37 & $-11.21(18.3)$ & $0.75,^{d} 1.14{ }^{d} 3.33^{a}$ \\
\hline$\left[\mathrm{Os}\left(\mathrm{PPh}_{3}\right)_{2}(\mathrm{CO})(\mathrm{H})\left(\mathrm{L}_{-}-\mathrm{OCH}_{2} \mathrm{CH}_{2} \mathrm{CH}_{2} \mathrm{CH}_{3}\right)\right]$ & $7.2-7.6$ & $8.05(8.8), 7.66(8.8)$ & 6.38 & $-11.21(18.6)$ & $0.79,^{a} 1.15,{ }^{d} 3.33^{a}$ \\
\hline
\end{tabular}

${ }^{a}$ Triplet. ${ }^{b}$ Singlet. ${ }^{c}$ Quartet. ${ }^{d}$ Multiplet. 
Table 4. Electronic Spectral and Cyclic Voltammetric Data

\begin{tabular}{|c|c|c|}
\hline compd & $\begin{array}{l}\text { electronic spectral data } \\
\lambda_{\max }, \operatorname{nm}\left(\epsilon, \mathrm{M}^{-1} \mathrm{~cm}^{-1}\right)\end{array}$ & $\begin{array}{c}\text { cyclic voltammetric data }^{a, b} \\
E, \mathrm{~V} \text { vs SCE }\end{array}$ \\
\hline$\left[\mathrm{Os}\left(\mathrm{PPh}_{3}\right)_{2}(\mathrm{CO})(\mathrm{H})\left(\mathrm{L}-\mathrm{OCH}_{2} \mathrm{CH}_{2} \mathrm{OCH}_{3}\right)\right]$ & $436(1630), 306(1300),{ }^{c} 274(12700),{ }^{c} 268(13700)^{c}$ & $0.77^{d}$ \\
\hline$\left[\mathrm{Os}\left(\mathrm{PPh}_{3}\right)_{2}(\mathrm{CO})(\mathrm{H})\left(\mathrm{L}-\mathrm{OCH}_{2} \mathrm{CH}_{3}\right)\right]$ & $420(1200), 334(2400),{ }^{c} 276(11500)^{c} 268(14461)^{c}$ & $0.69^{d}$ \\
\hline$\left[\mathrm{Os}\left(\mathrm{PPh}_{3}\right)_{2}(\mathrm{CO})(\mathrm{H})\left(\mathrm{L}-\mathrm{OCH}_{2} \mathrm{CH}_{2} \mathrm{CH}_{3}\right)\right]$ & $446(4900), 326(6700),{ }^{c} 276(13400),{ }^{c} 268(16200)^{c}$ & $0.88^{d}$ \\
\hline$\left[\mathrm{Os}\left(\mathrm{PPh}_{3}\right)_{2}(\mathrm{CO})(\mathrm{H})\left(\mathrm{L}-\mathrm{OCH}_{2} \mathrm{CH}_{2} \mathrm{CH}_{2} \mathrm{CH}_{3}\right)\right]$ & $436(4200), 310(5800),{ }^{c} 276(12700)^{c} 268(14800)^{c}$ & $0.78^{d}$ \\
\hline
\end{tabular}

${ }^{a}$ In dichloromethane. ${ }^{b}$ Supporting electrolyte, TBAP; scan rate $50 \mathrm{mV} \mathrm{s}^{-1} .{ }^{c}$ Shoulder. ${ }^{d}$ Anodic peak potential $\left(E_{\mathrm{pa}}\right)$.

coupling with the two phosphorus nuclei, near $-11.2 \mathrm{ppm}$. All the expected signals of the coordinated semicarbazone ligand have been clearly observed in all the complexes. The azomethine proton signal is observed as a singlet near 6.4 ppm, and signals for the two phenyl protons are observed as doublets near 7.7 and $8.0 \mathrm{ppm}$. The expected signals for the $\mathrm{R}^{\prime}$ groups in the semicarbazone ligand are observed within $0.75-3.48 \mathrm{ppm}$. The ${ }^{1} \mathrm{H}$ NMR spectral data of the $\left[\mathrm{Os}\left(\mathrm{PPh}_{3}\right)_{2}(\mathrm{CO})(\mathrm{H})\left(\mathrm{L}-\mathrm{OR}^{\prime}\right)\right]$ complexes are therefore consistent with their compositions.

Infrared spectra $\left(4000-600 \mathrm{~cm}^{-1}\right)$ of the $\left[\mathrm{Os}\left(\mathrm{PPh}_{3}\right)_{2}(\mathrm{CO})-\right.$ $\left.(\mathrm{H})\left(\mathrm{L}_{-} \mathrm{OR}^{\prime}\right)\right]$ complexes show many bands of different intensities (Table S1). Assignment of individual bands to specific vibrations has not been attempted. However, a strong band displayed near $1900 \mathrm{~cm}^{-1}$ by all the complexes indicates the presence of coordinated CO. ${ }^{10 f, g, i, 11}$ Another sharp band, observed near $2040 \mathrm{~cm}^{-1}$ in each complex, is assigned to the $v(\mathrm{Os}-\mathrm{H})$ stretch. ${ }^{10 \mathrm{f}, 12}$ Strong bands are also observed near 520, 695, and $750 \mathrm{~nm}$ in all the complexes due to the coordinated $\mathrm{PPh}_{3}$ ligands. ${ }^{3 a, b, 10 e, 13}$ Comparison of the infrared spectrum of each $\left[\mathrm{Os}\left(\mathrm{PPh}_{3}\right)_{2}(\mathrm{CO})(\mathrm{H})\left(\mathrm{L}-\mathrm{OR}^{\prime}\right)\right]$ complex with that of $\left[\mathrm{Os}\left(\mathrm{PPh}_{3}\right)_{2}(\mathrm{CO})_{2}(\mathrm{HCOO})_{2}\right]$ shows that some additional bands (e.g., strong bands near 1600, 1516, 1330 , and $\left.1025 \mathrm{~cm}^{-1}\right)$ are present in the spectra of the [Os$\left.\left(\mathrm{PPh}_{3}\right)_{2}(\mathrm{CO})(\mathrm{H})\left(\mathrm{L}-\mathrm{OR}^{\prime}\right)\right]$ complexes, which are attributable to the coordinated semicarbazone ligand. The $\left[\mathrm{Os}\left(\mathrm{PPh}_{3}\right)_{2}-\right.$ $\left.(\mathrm{CO})(\mathrm{H})\left(\mathrm{L}_{-} \mathrm{OR}^{\prime}\right)\right]$ complexes are soluble in dichloromethane, chloroform, acetone, acetonitrile, etc., producing intense orange solutions. Electronic spectra of the complexes have been recorded in dichloromethane solution. Spectral data are presented in Table 4, and a selected spectrum is shown in Figure 3. Each complex shows four intense absorptions, one in the visible region and three in the ultraviolet region. To have an idea about the nature of transitions responsible for these intense absorptions, qualitative EHMO calculations have been performed ${ }^{14}$ on computer generated models of all the four complex molecules, in which the phenyl rings of the $\mathrm{PPh}_{3}$ ligands have been replaced by hydrogens. A partial MO diagram is displayed in Figure 4. The molecular orbitals are found to be similar in composition for all the $\left[\mathrm{Os}\left(\mathrm{PPh}_{3}\right)_{2}\right.$ $\left.(\mathrm{CO})(\mathrm{H})\left(\mathrm{L}_{-}-\mathrm{OR}^{\prime}\right)\right]$ complexes (Table S2), which indicates that the $\mathrm{R}^{\prime}$ group does not have any appreciable influence on these molecular orbitals. In all the $\left[\mathrm{Os}\left(\mathrm{PPh}_{3}\right)_{2}(\mathrm{CO})(\mathrm{H})\left(\mathrm{L}-\mathrm{OR}^{\prime}\right)\right]$

(11) Diluzio, J. W.; Vaska, L. J. Am. Chem. Soc. 1961, 83, 1262.

(12) Laing, K. R.; Roper, W. R. J. Chem. Soc. A 1969, 1889.

(13) (a) Das, A. K.; Peng, S. M.; Bhattacharya, S. J. Chem. Soc., Dalton Trans. 2000, 181. (b) Dutta, S.; Peng, S. M.; Bhattacharya, S. Inorg. Chem. 2000, 39, 2231. (c) Dutta, S.; Peng, S. M.; Bhattacharya, S. J. Chem. Soc., Dalton Trans. 2000, 4623.

(14) (a) Mealli, C.; Proserpio, D. M. CACAO, version 4.0; Italy, 1994. (b) Mealli, C.; Proserpio, D. M. J. Chem. Educ. 1990, 67, 399.

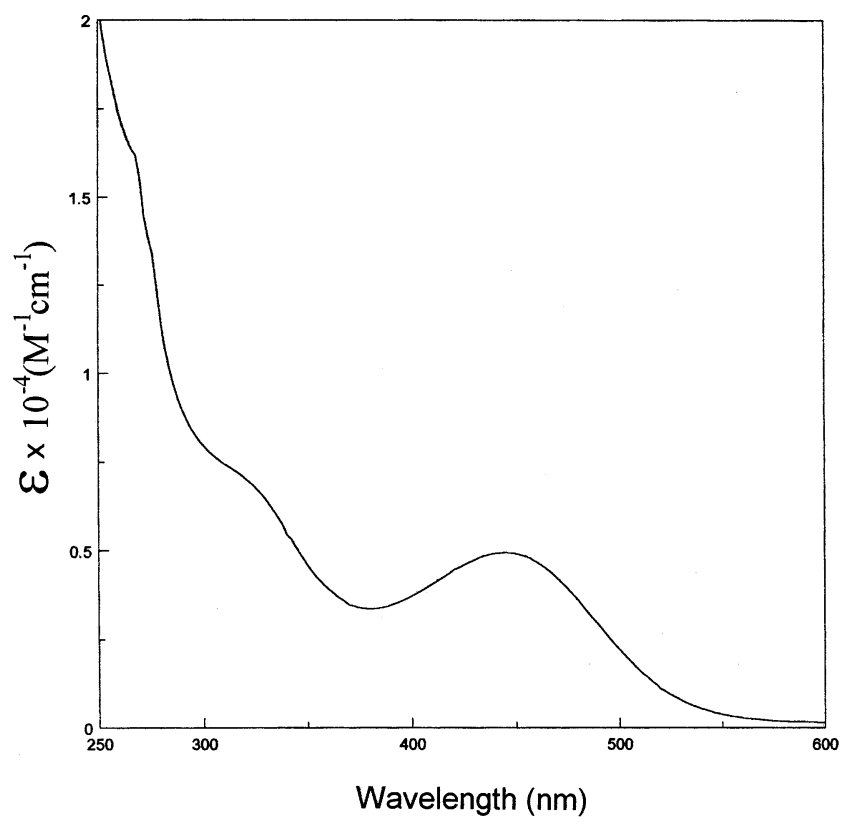

Figure 3. Electronic spectrum of $\left[\mathrm{Os}\left(\mathrm{PPh}_{3}\right)_{2}(\mathrm{CO})(\mathrm{H})\left(\mathrm{L}-\mathrm{OCH}_{2} \mathrm{CH}_{2} \mathrm{CH}_{3}\right)\right]$ in dichloromethane solution. (a)

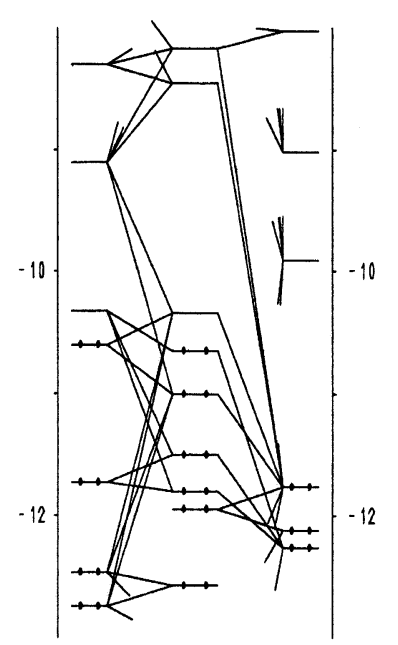

(b)

LUMO

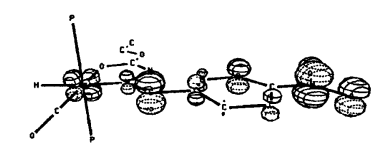

номо

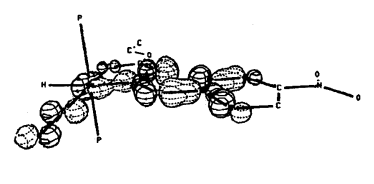

Figure 4. Partial molecular orbital diagram of $\left[\mathrm{Os}\left(\mathrm{PPh}_{3}\right)_{2}(\mathrm{CO})(\mathrm{H})(\mathrm{L}-\right.$ $\mathrm{OCH}_{2} \mathrm{CH}_{3}$ )]: (a) interaction diagram and (b) highest occupied and lowest unoccupied molecular orbitals.

complexes, the highest occupied molecular orbital (HOMO) has a major $(\geq 75 \%)$ contribution from the coordinated semicarbazone ligand, and a relatively much smaller contribution comes from the $\mathrm{CO}$ and osmium. A scrutiny of atomic contribution shows that the HOMO is localized mostly on the $-\mathrm{N}-\mathrm{N}=\mathrm{C}(\mathrm{H})-$ fragment of the semicarba- 
Gupta et al.

zone ligand and part of the phenyl ring linked to it. The lower filled orbitals [e.g., HOMO - 1 and HOMO - 2] have larger contributions from the metal center. The lowest unoccupied molecular orbital (LUMO) has more than $80 \%$ contribution from the semicarbazone ligand and is concentrated largely on the $\mathrm{NO}_{2}$ fragment of the semicarbazone ligand. The higher vacant orbitals (e.g., LUMO +1 and LUMO +2 ) are also localized on different parts of the semicarbazone ligand. The absorption in the visible region may therefore be assigned to the transition from the filled $\pi$-orbital (HOMO) delocalized over one part of the semicarbazone ligand to the vacant $\pi^{*}$ orbital (LUMO) concentrated on another part of the same ligand. In complexes of osmium(II) containing ligands with recognized chromophoric groups, usually metal $\left(\mathrm{t}_{2}\right)$-to-ligand$\left(\pi^{*}\right)$ charge-transfer transitions are observed in the visible region. ${ }^{15}$ The present $\left[\mathrm{Os}\left(\mathrm{PPh}_{3}\right)_{2}(\mathrm{CO})(\mathrm{H})\left(\mathrm{L}-\mathrm{OR}{ }^{\prime}\right)\right]$ complexes thus represent an interesting family where such MLCT transitions do not occur in the visible region.

Electrochemical properties of the $\left[\mathrm{Os}\left(\mathrm{PPh}_{3}\right)_{2}(\mathrm{CO})(\mathrm{H})(\mathrm{L}-\right.$ $\left.\mathrm{OR}^{\prime}\right)$ ] complexes have been studied by cyclic voltammetry in dichloromethane solution (0.1 M TBAP). Voltammetric data are given in Table 4. Each complex shows a one-electron oxidative response on the positive side of SCE, and keeping the results of the EHMO calculations in view, this is assumed to be a ligand(semicarbazone)-centered oxidation. This oxidation is irreversible for all the complexes, which indicates that the oxidized $\left[\mathrm{Os}\left(\mathrm{PPh}_{3}\right)_{2}(\mathrm{CO})(\mathrm{H})\left(\mathrm{L}-\mathrm{OR}^{\prime}\right)\right]^{+}$species,

(15) (a) Basuli, F.; Peng, S. M.; Bhattacharya, S. Polyhedron 1999, 18 , 391. (b) Kober, E. M.; Casper, J. V.; Sullivan, B. P.; Meyer, T. J. Inorg. Chem. 1988, 27, 4587. formed during the anodic scan, is unstable and undergoes rapid decomposition. The one-electron nature of this oxidation has been established by comparing its current height (anodic peak-current) with that of the standard ferrocene/ ferrocenium couple under identical experimental conditions.

\section{Conclusions}

The present study shows that benzaldehyde semicarbazone may undergo interesting metal-mediated transformation via nucleophilic attack by suitable species at the amide-like carbon center. Such possibilities are currently under exploration.

Acknowledgment. Financial assistance received from the University Grants Commission [Grant F.12-56/2001(SR-I)] is gratefully acknowledged. Thanks are also due to the Council of Scientific and Industrial Research, New Delhi [Grant 01(1675)/00/EMR-II], and the Department of Science and Technology, New Delhi [Grant No. SP/S1/F33/98], for financial assistance enabling the purchase of the electrochemical analyzer and the spectrophotometer used in this work. The authors thank the RSIC at Central Drug Research Institute, Lucknow, India, for the C,H,N analysis data. P.G. thanks CSIR for her fellowship.

Supporting Information Available: ${ }^{1} \mathrm{H}$ NMR spectra and tables containing yield and microanalytical and infrared spectral data (Table S1) and composition of selected molecular orbitals (Table $\mathrm{S} 2)$ of the $\left[\mathrm{Os}\left(\mathrm{PPh}_{3}\right)_{2}(\mathrm{CO})(\mathrm{H})\left(\mathrm{L}_{-} \mathrm{OR}^{\prime}\right)\right]$ complexes. X-ray crystallographic data in CIF format. This material is available free of charge via the Internet at http://pubs.acs.org.

IC026154S 